\title{
The Future of Rurality: Place Attachment among Young Inhabitants of Two Rural Communities of Mediterranean Central Chile
}

\author{
Paulina Rodríguez-Díaz ${ }^{1,2}{ }^{\circledR}$, Rocío Almuna ${ }^{1,3,4}$, Carla Marchant ${ }^{5}{ }^{\circledR}$, Sally Heinz ${ }^{1}$, Roxana Lebuy ${ }^{1}$, \\ Juan L. Celis-Diez ${ }^{6,7}$ (1) and Pablo Díaz-Siefer ${ }^{1,6, *(1)}$
}

check for updates

Citation: Rodríguez-Díaz, P.; Almuna, R.; Marchant, C.; Heinz, S.; Lebuy, R.; Celis-Diez, J.L.; Díaz-Siefer, P. The Future of Rurality: Place Attachment among Young Inhabitants of Two Rural

Communities of Mediterranean Central Chile. Sustainability 2022, 14, 546. https://doi.org/10.3390/ su14010546

Academic Editor: John McDonagh

Received: 18 September 2021

Accepted: 14 December 2021

Published: 5 January 2022

Publisher's Note: MDPI stays neutral with regard to jurisdictional claims in published maps and institutional affiliations.

Copyright: (c) 2022 by the authors. Licensee MDPI, Basel, Switzerland. This article is an open access article distributed under the terms and conditions of the Creative Commons Attribution (CC BY) license (https:// creativecommons.org/licenses/by/ $4.0 /)$.
1 Centro Regional de Investigación e Innovación para la Sostenibilidad de la Agricultura y los Territorios Rurales_CERES, Quillota 2260000,Chile; parodriguez6@uc.cl (P.R.-D.); rocio.am92@gmail.com (R.A.); sallyheinza@gmail.com (S.H.); rlebuy@centroceres.cl (R.L.)

2 Programa de Doctorado en Geografía, Instituto de Geografía, Pontificia Universidad Católica de Chile, Santiago 8320000, Chile

3 ECOS (Ecosystem-Complexity-Society) Co-Laboratory, Center for Local Development (CEDEL) \& Center for Intercultural and Indigenous Research (CIIR), Villarrica Campus, Pontificia Universidad Católica de Chile, Villarrica 4930000, Chile

4 School of Agriculture and Environment, Albany Campus, The University of Western Australia, Albany 6330, Australia

5 Instituto de Ciencias Ambientales y Evolutivas, Laboratorio de Estudios Territoriales LAbT UACh, Universidad Austral de Chile, Valdivia 5090000, Chile; carla.marchant@uach.cl

6 Escuela de Agronomía, Pontificia Universidad Católica de Valparaíso, Valparaíso 2340000, Chile; juan.celis@pucv.cl

7 Centro de Acción Climática, Pontificia Universidad Católica de Valparaíso, Santiago 8320000, Chile

* Correspondence: pablo.diaz@pucv.cl

\begin{abstract}
Rural livelihoods are under threat, not only from climate change and soil erosion but also because young people in rural areas are increasingly moving to urbanized areas, seeking employment and education opportunities. In the Valparaiso region of Chile, megadrought, soil degradation, and industrialization are driving young people to leave agricultural and livestock activities. In this study, our main objective was to identify the factors influencing young people living in two rural agricultural communities (Valle Hermoso and La Vega). We conducted 90 online surveys of young people aged 13-24 to evaluate their interest in living in the countryside (ILC). We assessed the effect of community satisfaction, connectedness to nature, and social valuation of rural livelihoods on the ILC. The results show that young people were more likely to stay living in the countryside when they felt satisfied and safe in their community, felt a connection with nature, and were surrounded by people who enjoyed the countryside. These results highlight the relevance of promoting place attachment and the feeling of belonging within the rural community. Chilean rural management and local policies need to focus on rural youth and highlight the opportunities that the countryside provides for them.
\end{abstract}

Keywords: rural exodus; rural livelihood; rural migration; rural youth; belonging

\section{Introduction}

The depopulation of rural areas is a demographic phenomenon worldwide [1-6] and is particularly relevant in Latin American countries [7], with societies shifting from agrarian to urban-industrial economies [8]. Previous studies show that the main factors driving the rural exodus are employment, recreational and education opportunities, together with the local effects of climate change and the decrease in agricultural productivity, due to the degradation and loss of soil fertility $[1,9,10]$. In this context, rural youth is a more geographically mobile demographic than rural adults [11]. Thus, the increasing exodus of young people from rural to urban areas threatens the stability of rural livelihoods $[1,12,13]$. 
Despite the aforementioned threats to agricultural productivity, rural areas are generally considered an attractive place to live due to their social and natural environment, and high quality of life [14-16]. In fact, rural youth who have a strong attachment to a place due to close relationships between community members, family and friends are most inclined to remain in their rural locality $[10,17,18]$. Altman and Low [19] assigned the term "place attachment" to the action of developing an emotional bond with places, consequently generating a bond with the physical and socio-cultural environment in which inhabitants develop their daily activities and personal experiences- this is considered a feel-good factor [20]. People develop these attachments to places where they feel secure and protected, and that they consider to be their home [21]. According to Riethmuller et al. [22], together with economic, educational, and interpersonal factors, place attachment is relevant to consider when addressing the motives for migration among rural young people, as well as their interest in returning to their rural roots.

In Latin America, the world's most urbanized region [7,23,24], rural youth face significant disadvantages and poverty levels higher than those of their urban counterparts, placing them as one of the most vulnerable social groups [25]. This scenario favors the exodus of the young rural population to urban areas [26,27]. In this context, Chile is no exception, since the centralism of the political-administrative system, along with the neoliberal economic model, has mainly promoted the tertiary and financial sectors. This has led to a lack of opportunities for young people in rural settlements and has had a detrimental effect on primary activities in rural areas, contributing to the urban-rural territorial imbalance [28]. An example of this is the centralized education system that drives young people to leave their rural homes and migrate to cities, which, in the long term, has a strong influence on definitive migration to urban centers [29].

In the Valparaiso region of central Chile, migration patterns can be influenced by factors such as water scarcity and the demographic aging process, among others [30]. According to the National Institute of Statistics [31], demographic aging, when projected to 2035, will be high in the Valparaiso region, with $22.2 \%$ of the population being over 65 years of age, making it the second-oldest demographic region in the country. Furthermore, from 2002 to 2017, the intercensal variation of the rural population between 13 and 24 years old in the Valparaiso region was $-4.1 \%$ [32]. Therefore, the sustainability of peasant family farming is under threat.

The motivation for this study emerged from workshops on a soil restoration project for degraded slopes, which was implemented with the assistance of two rural agricultural communities in the Valparaiso region (Valle Hermoso and La Vega), as part of the outreach activities of a research and development project. In these workshops, the communities voiced concerns about youth migration. Although young people seem to have a propensity for migration, as has been the trend in Latin America since the mid-twentieth century, different studies have underlined the desire shared by rural adults and youth to maintain rural continuity [33-36]. In the cases of the Valle Hermoso and La Vega communities, the conformation of the peasantry, as well as the development of local ancestral knowledge, are the result of a process of in situ cultural syncretism between creole and indigenous traditions. Additionally, the imminent disappearance of rural livelihoods is a relevant matter of concern among older peasants. Because of their historical dependence on agriculture, their cultural and emotional relationship with land ownership, and the rapid changes they are currently experiencing, these rural communities present an interesting case study to explore rural youth's interest in staying in the countryside, especially when considering that, on the one hand, Chile is one of the countries with the highest urbanization rates within the already urbanized Latin America [7]. On the other hand, Chile has an economic model based on international trade, which confers an excellent study model by which to project migration patterns in an increasingly globalized world. Therefore, the aim of this study is to identify the main factors that influence young rural people from Valle Hermoso and La Vega in their choice to live in the countryside. We target one specific question: what factors of place attachment should be encouraged to avoid youth depopulation? 


\section{Literature Review}

Understanding the characteristics of the youth that live in rural areas is essential to the future of these areas. Pardo [37] points out that the main characteristic of rural young people today is a higher educational level that makes them more flexible and open to innovation, better able to use new technologies, forms of socialization, and methods of acquisition of knowledge, making them relevant actors in their territories. However, their vision, voices, and interests have not been solicited, either in public policies or in the construction of dynamics for development. According to Díaz and Fernández [38], in Latin American countries, rural youth are in a situation of greater vulnerability concerning their urban peers, having fewer job opportunities for non-precarious employment and fewer possibilities of access to education, as well as higher rates of poverty. This generates a higher proportion of people who neither work nor study, especially in the case of young rural women.

\subsection{Community, Rural Livelihoods and Nature as Motivations for Living in the Countryside}

Previous studies have shown that the interest of rural youth in living in the countryside is related to both economic [39] and non-economic factors [40], in addition to structural and cultural factors [9]. Thus, the motivations of young people to migrate from or to return to rural places after completing their studies are influenced by family pressure, employment expectations, quality of life, personal background, environmental impacts on agriculture, lack of resources, and the local community environment [41,42].

People in rural areas tend to develop stronger attachments to their community than those in urban areas; therefore, leaving their community for educational or employment opportunities can be very difficult [22,43]. In this sense, community satisfaction is one of the factors influencing the young population exodus that, paradoxically, is affected by the same out-migration. The out-migration of young people can reduce the opportunities for social interaction for those who stay. Young people have less involvement in community organizations, sports and church groups, and other initiatives that nourish the local social capital $[44,45]$. This decline in the young population may harm the community satisfaction of the young people who stay.

The rural world has privileges that can impact young people's decision to develop their life projects in the countryside $[46,47]$. This has mainly been influenced by connectivity improvements and technical skills that facilitate mobility [48] and the rise of remote working triggered by the COVID-19 crisis. The pandemic has promoted an increased interest in rural spaces close to nature [49]. However, high rates of poverty and difficulties in access to certain goods and services in the countryside often make this alternative unattractive for many. For example, rural youth in economically distressed places must develop their plans in a context where educational and employment opportunities are generally found elsewhere, creating the need to migrate [50].

Furthermore, connectedness to nature, when understood as a personal attitude [51], is considered one of the multiple and dynamic dimensions of place attachment. Generally, young people express a positive attitude toward nature as an attractive aspect of rural places and positively link such places to their geographical background [52]. Haukanes [53] found that the arguments from those who prefer to live in the countryside are primarily based on the concept of the rural idyll, where the beauty of nature, tranquility, and air quality play a central role. However, in the scientific literature, the connectedness to nature is not usually considered an influential factor in the migration decision of rural youth. Our study aims to quantitatively assess whether rural youth's social and natural environment are factors that influence their interest in living in the countryside.

\subsection{Rural Development National Policy}

To date, in Chile, there is almost no territorial planning in rural areas [28], which makes it difficult to implement public policies that contribute to the development of the countryside and promote the interest of young people in staying. However, in 2018, new 
legislation on territorial planning was approved under law No. 21074 of the Government of Chile on strengthening regionalization. This laid the ground for a new approach to land-use planning, which involves the preparation of the National Rural Development Policy [28]. By this law, all instruments for territorial planning must be subject to this policy's requirements.

The National Rural Development Policy was approved and published in 2020 [54]. Its goal is to "improve the quality of life and increase the opportunities of the population living in rural territories, generating appropriate conditions for their integral development, through the gradual, planned and sustained adoption of a paradigm that conceives a public action with a territorial approach and that fosters synergies between public, private and civil society initiatives. In this way, the National Rural Development Policy expects to contribute to a greater territorial balance in the country, promoting the sustainable development of its smaller populated settlements". It focuses on four main areas: social goods; economic opportunities; environmental sustainability; and culture and identity. It is focused on the entire national rural territory, so all the territorial planning instruments must be in line with it. It includes a definition of rural territory, objectives and guiding principles, and the identification of key areas and strategic lines for rural development. It should be noted that this policy contemplates the strengthening, development, and articulation of programs and instruments that seek to satisfy the needs of groups that require priority attention, including children and youth.

\section{Materials and Methods}

\subsection{Study Site}

The study was performed in two agricultural communities in the Mediterranean zone of central Chile, specifically in the Valparaiso region: Valle Hermoso, located in the La Ligua district, and La Vega located in the Olmué district (see Figure 1). Both communities have similar characteristics, such as being agricultural communities whose origins date back to pre-Hispanic times $[55,56]$. Likewise, both places have shown a gradual abandonment of agriculture and livestock as the main economic activities. Another coincidence to note is the presence of a demographic dynamic characterized by a decrease in the young population: from 2002 to 2017, the intercensal variation of the rural population between 13 and 24 years old was $-1.6 \%$ in La Ligua and $-0.5 \%$ in Olmué [33]. Although the intercensal variation of the districts does not represent the region's trend, it should be noted that today, there are only 7 agricultural communities in the Valparaíso region that are undergoing a process of territorial fragmentation [57].

\subsection{Sampling}

We conducted an online survey (using Google Forms) among young people from 13 to 24 years old, to understand their interest in living and remaining in the countryside. The relevant fieldwork was conducted between February and March 2021. We involved both communities in order to maximize the sample size, since agricultural communities in the Valparaiso region are few in number and small in population. We calculated the sample size using Bartlett et al.'s [58] method for categorical data, considering an alpha level of $\alpha=0.1$ and $t$-value $=1.65$ as a desired level of precision (as used by, e.g., [59]). This calculation estimated a sample size of 58 rural young people. However, we decided to collect at least 100 responses to utilize a more conservative approach. Community leaders and members provided us with a list of 61 young people, who were contacted directly via phone call, and the survey was sent via WhatsApp. Furthermore, we also used a chain-sampling method among the members of the communities in order that the survey could reach more young people. It should be noted that we started with physical surveys, but due to the COVID-19 pandemic, we adapted to an online format. 


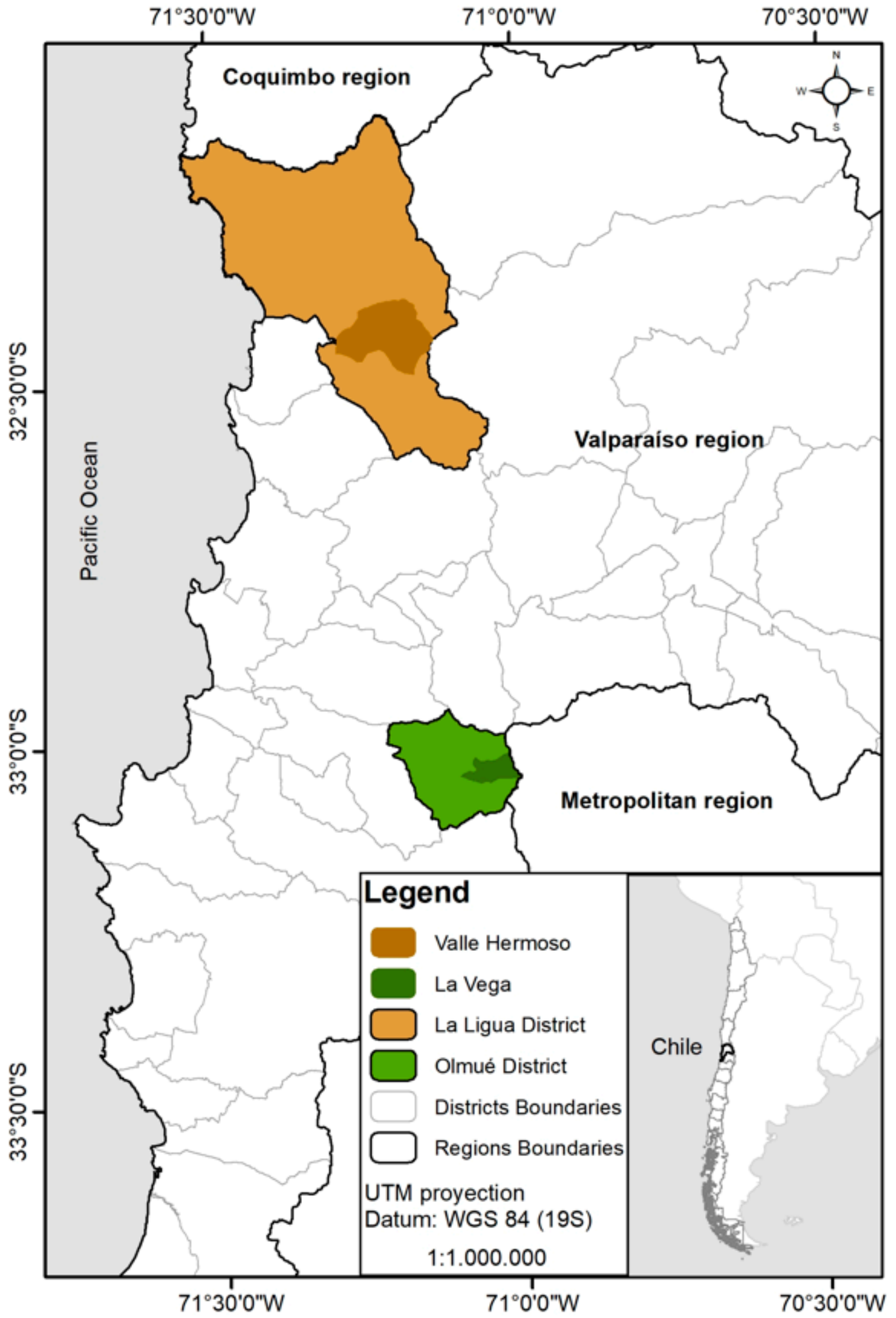

Figure 1. Location of the two rural communities from Mediterranean central Chile.

\subsection{Measures}

To measure the main factors that influence young people to live in the countryside, we designed a survey with two main sections: (i) demographic questions to gather information 
on the socioeconomic and cultural profile of the respondents; (ii) questions related to the interest of rural young people in living in the countryside. The survey instrument was piloted on 17 young volunteers from a different rural community to those taking part in this study in order to adjust timing and to assess the respondents' understanding of the individual items.

The first section had 20 data points relating to their personal information (age, gender, education, place of residence, and studies), family characteristics (parents' educational level and family's economic activity), and their participation in farm-related work. In the second section, we designed 4 different 5-point Likert scales with 36 items in total to assess the interest of rural youth in living in the countryside (Supplementary Material Figure S1). The 4 scales were: (1) interest in living in the countryside (hereafter, ILC) related to the respondents' projection to live in the countryside; (2) community satisfaction (hereafter, CS), related to the level of satisfaction of the rural youth with the people, rural environment, and rural livelihoods of their community; (3) connectedness to nature (hereafter, CN), associated with the affective and physical relationship that rural youth have with the natural world; (4) social valuation of rural livelihoods (hereafter, SVRL), related to the influence exerted by the social environment over young rural people (see Supplementary Material Table S1 for details of the items of each scale). The wording of some items was modified to facilitate the respondents' understanding and to better suit Chilean idiosyncrasies.

\subsection{Data Analysis}

All the statistical analyses were conducted using the statistical software R v4.0.4 [60], considering a significance level of 0.05 . First, we used Cronbach's alpha reliability analysis to estimate the internal consistency of each scale in Section 2, which were ILC, CS, CN, and SVRL, using the psych package [61]. We treated the scale scores as ordinal data; therefore, we performed nonparametric statistics to analyze these scores $[62,63]$. Thus, to establish which factors of place attachment should be encouraged to avoid youth depopulation, Spearman's rho correlation coefficients were used to analyze the association between the ILC and the other variables of interest. Finally, a nonparametric quantile regression (hereafter, NQR) was performed with ILC as a dependent variable and CS, CN, and SVRL as predictors, using the quantreg package [64]. We chose to use NQR because it allows for the estimation at various quantiles of the dependent variable, rather than presuming a uniform mean effect, without making assumptions about the distribution of the dependent variable [65].

\section{Results}

\subsection{Socioeconomic and Cultural Characteristics of Respondents}

We received 106 responses; however, 16 were excluded due to erroneous duplication $(n=11)$ and ages out of range $(n=5)$, leaving a final sample of 90 young people from the two communities. It should be noted that we produced three physical surveys. The average age of the respondents was $18 \pm 3.2$ years, with $50 \%$ women $(n=45)$ and $50 \%$ men $(n=45)$. In addition, the respondents tended to develop their studies within the place where they grew up $(40 \%)$, or in another place that was still within the Valparaiso region $(38.9 \%)$. The majority of respondents had never lived outside their rural community $(70 \%)$; those who had lived beyond it had done so mainly due to their studies. The families were mostly engaged in agriculture (51.1\%) and textile production (36.7\%). Regarding countryside activities, $84.4 \%$ fed and cared for animals, $64.4 \%$ harvested, and $57.7 \%$ prepared the soil and sowed (Supplemental Material Table S2 and Figure S2).

\subsection{Interest in Living in the Countryside}

All measure scales showed good reliability: ILC (Cronbach's $\alpha=0.77)$, CS (Cronbach's $\alpha=0.71), \mathrm{CN}$ (Cronbach's $\alpha=0.71$ ) and SVRL (Cronbach's $\alpha=0.65)$. Respondents showed a mean score $\pm \mathrm{SE}$ of $3.66 \pm 0.01$ for ILC, $3.67 \pm 0.06$ for CS, $4.46 \pm 0.06$ for $\mathrm{CN}$ and $3.72 \pm 0.05$ for SVRL. 
Spearman's correlation coefficients, between ILC and the other three scales, are presented in Table 1. All correlations showed moderate strength. The results show that higher scores on ILC were positively related to higher scores on CS, and the same occurred between CN and SVRL (all were $p<0.01$ ). In addition, CS, CN, and SVRL are related to each other.

Table 1. Spearman correlation tests between ILC and CS, CN and SVRL.

\begin{tabular}{ccccc}
\hline Variable & ILC & CS & CN & SVRL \\
\hline ILC & & & \\
CS & $0.404^{* *}$ & & \\
CN & $0.524^{* *}$ & $0.432^{* *}$ & $0.336^{* *}$ & \\
SVRL & $0.480^{* *}$ & $0.447^{* *}$ & \\
\hline
\end{tabular}

Abbreviations: ILC: interest in living in the countryside; CS: community satisfaction; CN: connectedness to nature SVRL: social valuation of rural livelihoods. ${ }^{* *}$ Represents statistical significance at the 0.01 level.

The results of the NQR between ILC and each factor are provided in Table 2. The NQR showed that there is a positive effect of CS on all the quantiles of ILC; thus, if a young person feels satisfied living within their community, or if they feel safe living in it, they will show more interest in staying in the countryside. Similarly, CN had a positive effect on all quantiles of ILC, reflecting that the more connected a young person is to their natural surroundings and biodiversity, the more interest they will show in living in the countryside. Finally, there is a positive effect of SVRL on all quantiles of ILC, meaning that the social environment has an influence on young people; specifically, when there is a transfer of knowledge about field activities, or when friends find it appealing to stay in the countryside, this contributes to the young people's desire to live near them or practice the same activities. Therefore, the effect of the three factors on interest in living in the countryside is constant across the conditional distribution of ILC. In addition, the effect of the three factors on ILC showed an asymmetric dependence structure with a left-tail dependence (i.e., the factors have a greater influence on the lower quantiles of the ILC).

Table 2. Nonparametric quantile regressions, estimated at the $0.2,0.4,0.6$, and 0.8 quantiles of ILC. The value in parentheses represents the standard error (SE).

\begin{tabular}{ccccc}
\hline \multirow{2}{*}{ Variable } & \multicolumn{5}{c}{ ILC } \\
\cline { 2 - 5 } & Q0.2 (SE) & Q0.4 (SE) & Q0.6 (SE) & Q0.8 (SE) \\
\hline CS & $1.25(0.31)^{* *}$ & $1.25(0.31)^{* *}$ & $1.25(0.31)^{* *}$ & $1.25(0.31)^{* *}$ \\
CN & $0.59(0.27)^{*}$ & $0.59(0.27)^{*}$ & $0.59(0.27)^{*}$ & $0.59(0.27)^{*}$ \\
SVRL & $0.63(0.26)^{* *}$ & $0.63(0.26)^{* *}$ & $0.63(0.26)^{* *}$ & $0.63(0.26)^{* *}$ \\
\hline
\end{tabular}

Abbreviations: ILC: interest in living in the countryside; CS: community satisfaction; CN: connectedness to nature; SVRL: social valuation of rural livelihoods. * Represents statistical significance at the 0.05 level. ** Represents statistical significance at the 0.01 level.

\section{Discussion}

Our results show that when young people were satisfied with their community surroundings, they were likely to develop a strong place attachment and, hence, were more interested in living in the countryside $[18,66]$. In addition, the CS scale is related to people, rural environment, and rural livelihoods within the community. This could explain the positive correlation between CS and CN, and SVRL. Therefore, satisfaction with their social and natural environment could promote a desire in rural youth for this lifestyle. In addition, our study contributes to the few published quantitative studies that consider both the natural and the social environment in order to determine young people's interest in living in the countryside (e.g., [18]).

Social environment strongly influenced place attachment [19], explaining the positive relationship between interest in living in the countryside and social valuation. A rural livelihood comprises the possibilities, assets-including both material and social resources- 
and activities necessary to earn a living [46]; thus, the social valuation of rural livelihoods could influence the decision to migrate from the countryside. Similarly, previous studies have shown that the family circle contributes to stimulating the permanence of young people in the countryside $[13,41]$. Moreover, family and friends are relevant motivations for returning to the local rural communities for those who have migrated [67-70]. Thus, to strengthen our findings, future research could consider rural young people who migrated to cities, because work and family expectations and the identity of young subjects are closely linked to the imaginary ideal of the city [71].

The shared outdoor spaces of a community are essential for the satisfaction of its members, mainly because of the opportunities to visit natural areas and have countryside views [72]. Connectedness to nature was the scale with the highest score (mean $\pm \mathrm{SE}=4.46 \pm 0.06$ ). In fact, young people living in rural areas have a strong connection with nature in comparison with young people in urban areas [73-75], probably because rural youth usually spend more time outdoors. Thus, $\mathrm{CN}$ was the scale more related to ILC $(\mathrm{r}=0.524, p \leqq 0.01)$. This strong connection with nature can promote a strong place attachment $[52,76,77]$ and, therefore, a greater interest in living in the countryside. This is in line with previous studies that have shown that nature is an important factor motivating young people to stay in their rural communities, meaning that the natural environment and outdoor recreation have the potential to create a sense of attachment in young people to their homes [14,18,52]. However, today, increased access to screens may have a detrimental effect on the connection with nature among new generations [78,79], which is why future studies should consider the influence of screens and technology on interest in living in the countryside.

The rural landscape, which includes agricultural and natural areas, has a historicalcultural value and, therefore, offers excellent potential for agrotourism, which can become an opportunity for local development $[80,81]$ and help reduce youth migration. Unfortunately, the expansion of the agri-business model, through the extensive replacement of natural areas, not only contributes to the loss of biodiversity but also to the loss of ecosystem services, resulting in a degradation of the landscape and potentially leading to rural youth migration, due to the loss of people's well-being [82]. Thus, access to land often constitutes a barrier for those young people who wish to remain in the countryside and develop an enterprise [83].

Our results can constitute a tool for future rural management and local policies for promoting rural livelihoods, which should focus on the enhancement of the relationship between people, rural livelihoods, and natural areas of the local community in order to increase community satisfaction and, consequently, place attachment. For example, schools could promote a feeling of belonging to the community and the development of a rural identity among young people; municipalities could make rural youth aware of the potentialities of employment and entrepreneurship opportunities in rural areas and promote their local festivals and cultural practices, to create ties within the community. However, this must always be carried out in permanent dialog with the local community. This can certainly mesh with the Chilean Rural Development National Policy [55], which considers children, teenagers, and young adults as being among the priority groups for programs and instruments focused on integrated rural development. In the current context of the global COVID-19 pandemic, this has become particularly urgent. This pandemic has exposed the need for rethinking urban lifestyles and, as rural spaces are increasingly sought after, it is possible that a scenario of greater pressure and disputes for rural territories may emerge in the future.

\section{Conclusions}

The depopulation of rural areas is an important challenge for the sustainability of rural territories in Latin American countries [1-7]. Our results showed that a young person who feels satisfied in their community, connected to the natural surroundings, and whose family and friends had a positive valuation of the countryside is more interested in the countryside. This contributes to the evidence that both social relationships and connection 
to the natural environment are important factors in a young person's decision to live in a place similar to where he or she grew up. These results highlight how relevant it is to promote place attachment and the feeling of belonging within the rural community, which translates into young people's interest in living in the countryside. Accordingly, Chilean rural management and local policies should focus not only on economic or employment issues but also on improving young people's social and natural environment valuation to increase their place attachment, promoting local festivals and cultural practices to create ties within the community.

Supplementary Materials: The following are available online at https: / www.mdpi.com/article/ 10.3390/su14010546/s1, Table S1: Scales questionnaire developed in this study, Table S2: Sociodemographic characteristics of respondents $(n=90)$, Figure S1: Main drivers of depopulation of rural areas according to the pull-push approach, Figure S2: Sociodemographic data of our study, locality, and region.

Author Contributions: Conceptualization, P.D.-S.; methodology, P.R.-D., C.M., S.H., R.L. and P.D.-S.; data acquisition, P.R.-D. and S.H.; formal analysis, P.D.-S.; writing-original draft preparation, P.R.-D., R.A. and P.D.-S.; writing—review and editing, P.R.-D., R.A., C.M., S.H., R.L., J.L.C.-D. and P.D.-S. All authors have read and agreed to the published version of the manuscript.

Funding: This research was funded by the Agencia Nacional de Investigación y Desarrollo ANID, Chile (https:/ / www.anid.cl accessed on 5 November 2021) through the grants ANID/REGIONAL/ R19F10017 and ANID REGIONAL/CERES/R19A1002. J.L.C.-D. and P.D.-S. were supported by ANID/PIA/ACT192027. P.R.-D. was funded by the ANID doctoral scholarship grant No2121239.

Institutional Review Board Statement: Not applicable.

Informed Consent Statement: Informed consent was obtained from all subjects involved in the study. Data Availability Statement: Not applicable.

Acknowledgments: The authors acknowledge the collaboration of members of rural communities for their contribution to the survey presented in this article. J.L.C.-D. is an associate researcher at the Institute of Ecology and Biodiversity (IEB).

Conflicts of Interest: The authors declare no conflict of interest. The funders had no role in the design of the study; in the collection, analyses, or interpretation of data; in the writing of the manuscript, or in the decision to publish the results.

\section{References}

1. Bjarnason, T.; Thorlindsson, T. Should I stay or should I go? Migration expectations among youth in Icelandic fishing and farming communities. J. Rural Stud. 2006, 22, 290-300. [CrossRef]

2. Bayona-i-Carrasco, J.; Gil-Alonso, F. Is Foreign Immigration the Solution to Rural Depopulation? The Case of Catalonia (1996-2009). Sociol. Rural. 2013, 53, 26-51. [CrossRef]

3. Vásquez Wiedeman, C.; Vallejos Quilodrán, D. Migración juvenil rural en la región del Maule, Chile. Rev. Cienc. Soc. 2014, 27, 91-108.

4. Johnson, K.M.; Lichter, D.T. Rural Depopulation: Growth and Decline Processes over the Past Century. Rural Sociol. 2019, 84, 3-27. [CrossRef]

5. Rodríguez-Soler, R.; Uribe-Toril, J.; De Pablo Valenciano, J. Worldwide trends in the scientific production on rural depopulation, a bibliometric analysis using bibliometrix R-tool. Land Use Policy 2020, 97, 104787. [CrossRef]

6. Yeboah, T. Future aspirations of rural-urban young migrants in Accra, Ghana. Child. Geogr. 2021, 19, 45-58. [CrossRef]

7. Rozzi, R. Biocultural Ethics: From Biocultural Homogenization toward Biocultural Conservation. In Linking Ecology and Ethics for a Changing World: Ecology and Ethics; Rozzi, R., Pickett, S., Palmer, C., Armesto, J., Callicott, J., Eds.; Springer: Dordrecht, The Netherlands, 2013; Volume 1, pp. 9-32. [CrossRef]

8. Li, Y.; Westlund, H.; Liu, Y. Why some rural areas decline while some others not: An overview of rural evolution in the world. J. Rural Stud. 2019, 68, 135-143. [CrossRef]

9. Thissen, F.; Fortuijn, J.D.; Strijker, D.; Haartsen, T. Migration intentions of rural youth in the Westhoek, Flanders, Belgium and the Veenkoloniën, The Netherlands. J. Rural Stud. 2010, 26, 428-436. [CrossRef]

10. Mclaughlin, D.K.; Shoff, C.M.; Demi, M.A. Influence of Perceptions of Current and Future Community on Residential Aspirations of Rural Youth. Rural Sociol. 2014, 79, 453-477. [CrossRef] 
11. Cazzuffi, C.; Fernández, J. Rural Youth and Migration in Ecuador, Mexico and Peru; Serie documento de trabajo $\mathrm{N}^{\circ} 235$. Programa $^{2}$ Jóvenes Rurales, Territorios y Oportunidades: Una estrategia de diálogos de políticas; RIMISP: Santiago, Chile, 2018.

12. Stockdale, A. Out-migration from rural Scotland: The importance of family and social networks. Sociol. Rural. 2002, 42, 41-64 [CrossRef]

13. Llorent-Bedmar, V.; Cobano-Delgado Palma, V.C.; Navarro-Granados, M. The rural exodus of young people from empty Spain. Socio-educational aspects. J. Rural Stud. 2021, 82, 303-314. [CrossRef]

14. Gosnell, H.; Abrams, J. Amenity migration: Diverse conceptualizations of drivers, socioeconomic dimensions, and emerging challenges. GeoJournal 2011, 76, 303-322. [CrossRef]

15. Lichter, D.T.; Brown, D.L. Rural America in an urban society: Changing spatial and social boundaries. Annu. Rev. Sociol. 2011, 37, 565-592. [CrossRef]

16. Marchant, C.; Rojas, F. Transformaciones locales y nuevas funcionalidades económicas vinculadas a las migraciones por amenidad en la Patagonia chilena. Rev. Géographie Alp. 2015, 105, 1-19. [CrossRef]

17. Glendinning, A.; Nuttall, M.; Hendry, L.; Kloep, M.; Wood, S. Rural communities and well-being: A good place to grow up? Sociol. Rev. 2003, 51, 129-156. [CrossRef]

18. Ulrich-Schad, J.D.; Henly, M.; Safford, T.G. The role of community assessments, place, and the great recession in the migration intentions of Rural Americans. Rural Sociol. 2013, 78, 371-398. [CrossRef]

19. Altman, I.; Low, S. Place Attachment; Plenum Press: New York, NY, USA, 1992.

20. Dallimer, M.; Irvine, K.N.; Skinner, A.M.J.; Davies, Z.G.; Rouquette, J.R.; Maltby, L.L.; Warren, P.H.; Armsworth, P.R.; Gaston, K.J. Biodiversity and the feel-good factor: Understanding associations between self-reported human well-being and species richness. Bioscience 2012, 62, 47-55. [CrossRef]

21. Hernández, B. Place attachment: Antecedents and consequences (Antecedentes y consecuencias del apego al lugar). Psyecology 2021, 12, 99-122. [CrossRef]

22. Riethmuller, M.L.; Dzidic, P.L.; Newnham, E.A. Going rural: Qualitative perspectives on the role of place attachment in young people's intentions to return to the country. J. Environ. Psychol. 2021, 73, 101542. [CrossRef]

23. CEPAL. Población, Territorio y Desarrollo Sostenible; Naciones Unidas: Santiago, Chile, 2012.

24. Rozzi, R. Biocultural Ethics: From Biocultural Homogenization toward Biocultural Conservation. In Linking Ecology and Ethics for a Changing World: Values, Philosophy, and Action; Rozzi, S., Pickett, C., Palmer, J., Armesto, J.J., Callicott, J.B., Eds.; Springer: New York, NY, USA, 2014; pp. 9-32.

25. Guiskin, M. Situación de las Juventudes Rurales en América Latina y el Caribe; Serie Estudios y Perspectivas-CEPAL: Mexico City, Mexico, 2019.

26. Sili, M.; Fachelli, S.; Meiller, A. Juventud Rural: Factores que influyen en el desarrollo de la actividad agropecuaria. Reflexiones sobre el caso argentino. Rev. Econ. Sociol. Rural. 2017, 54, 635-652. [CrossRef]

27. RIMISP. Juventud Rural y Territorio; Pobreza y Desigualdad Informe Latinoamericano: Santiago, Chile, 2019.

28. Rojas, F.; Rodríguez, P.; Marchant, C.; Troncoso, R. Los espacios rurales en Chile. Reflexiones sobre sus transformaciones e implicancias en las últimas cuatro décadas. In Chile Cambiando: Revisitando la geografía Regional de Wolfgang Weischet; Borsdorf, A., Marchant, C., Rovira, A., Sanchez, R., Eds.; Serie GEOlibros: Santiago, Chile, 2020; Volume 1, pp. 621-679.

29. Núcleo Milenio Centro para el Impacto Socioeconómico de las Políticas Ambientales (CESIEP). Estudio de Indicadores de Calidad de Vida y Estándares de Vida en los Territorios Rurales de Chile; ODEPA: Santiago, Chile, 2019.

30. Instituto Nacional de Estadística (INE). Estimaciones y Proyecciones a Nivel Regional de la Población de Chile 2002-2035; INE: Santiago, Chile, 2020.

31. Instituto Nacional de Estadística (INE). Estimaciones y Proyecciones de la Población de Chile 2002-2035. In Totales Regionales, Población Urbana Y Rural. Sintesis de Resultados; INE: Santiago, Chile, 2019.

32. Instituto Nacional de Estadística (INE). Redatam Diseminación de Datos. Available online: https://redatam-ine.ine.cl/ (accessed on 14 May 2021).

33. Abramovay, J.; Silvestre, M.; Cortina, N.; Baldissera, I.; Ferrari, D.; Testa, V. Sucessao proffissional e transferencia hereditaria na agricultura familiar. In Proceedings of the X Congreso Mundial de Sociología Rural, Río de Janeiro, Brazil, 2 August 2000.

34. Caputo, L. Identidades Trastocadas de la Juventud Rural en Contexto de exclusión. Ensayando una reflexión Sobre la Juventud Campesina Paraguaya; Documento de Trabajo no. 102; CLACSO: Asuncion, Paraguay, 2001.

35. Weisheimer, N. Os jovens agricultores e o processo de trabalho da agricultura familiar. In Proceedings of the VI Congreso de la Asociación Latinoamericana de Sociología, Porto Alegre, Brazil, 27 November 2002.

36. Kessler, G. La investigación social sobre juventud rural en América Latina. Estado de la cuestión de un campo en conformación. Rev. Colomb. Educ. 2006, 51, 16-39. [CrossRef]

37. Pardo, R. Dianóstico de la Juventud Rural en Colombia. Grupos de Diálogo Rural, una Estrategia de Incidencia; Serie documento N²27. Grupo de Trabajo Inclusión Social y Desarrollo. Programa Jóvenes Rurales, Territorios y Oportunidades: Una estrategia de diálogos de políticas; Rimisp: Santiago, Chile, 2017.

38. Díaz, V.; Fernández, J. ¿Qué Sabemos de los Jóvenes Rurales? Síntesis de la Situación los Jóvenes Rurales en Colombia, Ecuador, México y Perú; Serie documento de Trabajo № 228, Grupo de Trabajo Inclusión Social y Desarrollo. Programa Jóvenes Rurales, Territorios y Oportunidades: Una estrategia de diálogos de políticas; Rimisp: Santiago, Chile, 2017.

39. Stockdale, A. Migration: Pre-requisite for rural economic regeneration? J. Rural Stud. 2006, 22, 354-366. [CrossRef] 
40. Garasky, S. Where are they going? A comparison of urban and rural youths' locational choices after leaving the parental home. Soc. Sci. Res. 2002, 31, 409-431. [CrossRef]

41. Bednaříková, Z.; Bavorová, M.; Ponkina, E.V.P. Migration motivation of agriculturally educated rural youth: The case of Russian Siberia. J. Rural Stud. 2016, 45, 99-111. [CrossRef]

42. Pelzom, T.; Katel, O. Youth Perception of Agriculture and potential for employment in the context of rural development in Bhutan. Dev. Environ. Foresight 2017, 3, 2336-6621.

43. Anton, C.; Lawrence, C. Home is where the heart is: The effect of place of residence on place attachment and community participation. J. Environ. Psychol. 2014, 40, 451-461. [CrossRef]

44. Alston, A. 'You don't want to be a check-out chick all your life': The out-migration of young people from Australia's small rural towns. Aust. J. Soc. 2004, 39, 299-313. [CrossRef]

45. Tonts, M. Competitive sport and social capital in rural Australia. J. Rural Stud. 2005, 21, 137-149. [CrossRef]

46. Chambers, R.; Conway, G. Sustainable Rural Livelihoods: Practical Concepts for the 21st Century; Institute of Development Studies: Brighton, UK, 1991.

47. Shucksmith, M. Young People and Social Exclusion in Rural Areas. Sociol Rural. 2004, 44, 43-59. [CrossRef]

48. Pérez, G. Caminos Rurales: Vias Claves Para la Producción, la Conectividad y el Desarrollo Territorial; Boletín FAL N³77; CEPAL: Santiago, Chile, 2020; Available online: https://hdl.handle.net/11362/45781 (accessed on 23 May 2021).

49. Phillipson, J.; Gorton, M.; Turner, R.; Shucksmith, M.; Aitken-McDermott, K.; Areal, F.; Cowie, P.; Hubbard, C.; Maioli, S.; McAreavey, R.; et al. The COVID-19 Pandemic and Its Implications for Rural Economies. Sustainability 2020, 12, 3973. [CrossRef]

50. Kirkpatrick Johnson, M.; Elder, G.H.; Stern, M. Attachments to family and community and the young adult transition of rural youth. J. Res. Adolesc. 2005, 15, 99-125. [CrossRef]

51. Brügger, A.; Kaiser, F.G.; Roczen, N. One for all?: Connectedness to nature, inclusion of nature, environmental identity, and implicit association with nature. Eur. Psychol. 2011, 16, 324-333. [CrossRef]

52. Wiborg, A. Place, nature and migration: Student's attachment to their rural home places. Sociol. Rural. 2004, 44, 416-432. [CrossRef]

53. Haukanes, H. Belonging, Mobility and the Future: Representations of Space in the Life Narratives of Young Rural Czechs. Young 2013, 21, 193-210. [CrossRef]

54. Ministerio del Interior y Seguridad Pública. Política Nacional de Desarrollo Rural; Diario Oficial: Santiago, Chile, 2020.

55. Godoy, M.; Contreras, H. Continuidad y cambio en una comunidad indígena del Norte Chico: Valle Hermoso, 1650-1950. In Experiencias de Historia Regional en Chile: Tendencias historiográficas Actuales; Cáceres, J., Ed.; Instituto de Historia PUCV: Valparaíso, Chile, 2008; pp. 219-237.

56. Moyano, C. Oficios Campesinos del Valle de Aconcagua; Ediciones Inubicalistas: Valparaíso, Chile, 2014.

57. Razeto Migliaro, J.; Catalán Martina, E.; Skewes Vodanovic, J.C. Soberanía territorial, conservación ambiental y comunidades de campo común en Chile central. Polis Rev. Latam. 2019, 54, 75-89. [CrossRef]

58. Bartlett, J.E., II; Kotrlik, J.W.; Higgins, C.C. Organizational Research: Determining appropriate sample size in survey research. Inf. Technol. Learn. Perform. J. 2001, 19, 43-50.

59. Almuna, R.; Cruz, J.M.; Vargas, F.H.; Ibarra, J.T. Landscapes of coexistence: Generating predictive risk models to mitigate human-raptor conflicts in forest socio-ecosystems. Biol. Conserv. 2020, 251, 108795. [CrossRef]

60. R Core Team. R: A Language and Environment for Statistical Computing; R Foundation for Statistical Computing: Vienna, Austria, 2021.

61. Revelle, W. Psych: Procedures for Psychological, Psychometric, and Personality Research; R Package Version 2.1.6; Northwestern University: Evanston, IL, USA, 2021.

62. Göb, R.; McCollin, C.; Ramalhoto, M.F. Ordinal methodology in the analysis of likert scales. Qual. Quant. 2007, 41, 601-626. [CrossRef]

63. Gardner, H.J.; Martin, M.A. Analyzing ordinal scales in studies of virtual environments: Likert or lump it! Presence Teleoperators Virtual Environ. 2007, 16, 439-446. [CrossRef]

64. Koenker, R.; Chernozhukov, V.; He, X.; Peng, L. (Eds.) Handbook of Quantile Regression; CRC Press, Taylor \& Francis Group: Boca Raton, FL, USA, 2017. [CrossRef]

65. Koenker, R.; Hallock, K.F. Quantile regression. J. Econ. Perspect. 2001, 15, 143-156. [CrossRef]

66. Hummon, D. Community Attachment: Local Sentiment and Sense of Place. In Place Attachment; Altman, I., Low, S., Eds.; Plenum Press: New York, NY, USA, 1992; pp. 253-278.

67. Von Reichert, C. Returning and New Montana Migrants: Socio-economic and Motivational Differences. Growth Chang. 2001, 32, 447-465. [CrossRef]

68. Wang, W.W.; Fan, C.C. Success or failure: Selectivity and reasons of return migration in Sichuan and Anhui, China. Environ. Plan. A 2006, 38, 939-958. [CrossRef]

69. Niedomysl, T.; Amcoff, J. Why Return Migrants Return: Survey Evidence on Motives for Internal Return Migration in Sweden. Popul. Space Place 2011, 17, 656-673. [CrossRef]

70. Haartsen, T.; Thissen, F. The success-failure dichotomy revisited: Young adults' motives to return to their rural home region. Child. Geogr. 2014, 12, 87-101. [CrossRef] 
71. Jurado, C.; Tobasura, I. Dilema de la juventud en territorios rurales de Colombia: ¿campo o ciudad? Rev. Latinoam. Cienc. Soc. Niñez Juv. 2012, 10, 63-77.

72. Kearney, A.R. Residential development patterns and neighborhood satisfaction: Impacts of density and nearby nature. Environ Behav. 2006, 38, 112-139. [CrossRef]

73. Fränkel, S.; Sellmann-Risse, D.; Basten, M. Fourth graders' connectedness to nature-Does cultural background matter? J. Environ. Psychol. 2019, 66, 101347. [CrossRef]

74. Duron-Ramos, M.F.; Collado, S.; García-Vázquez, F.I.; Bello-Echeverria, M. The Role of Urban/Rural Environments on Mexican Children's Connection to Nature and Pro-environmental Behavior. Front. Psychol. 2020, 11, 514. [CrossRef]

75. Soga, M.; Gaston, K.J. Extinction of experience: The loss of human-nature interactions. Front. Ecol. Environ. 2016, 14, 94-101. [CrossRef]

76. Gosling, E.; Williams, K.J.H. Connectedness to nature, place attachment and conservation behaviour: Testing connectedness theory among farmers. J. Environ. Psychol. 2010, 30, 298-304. [CrossRef]

77. Basu, M.; Hashimoto, S.; Dasgupta, R. The mediating role of place attachment between nature connectedness and human well-being: Perspectives from Japan. Sustain. Sci. 2020, 15, 849-862. [CrossRef]

78. Larson, L.R.; Szczytko, R.; Bowers, E.P.; Stephens, L.E.; Stevenson, K.T.; Floyd, M.F. Outdoor Time, Screen Time, and Connection to Nature: Troubling Trends Among Rural Youth? Environ. Behav. 2019, 51, 966-991. [CrossRef]

79. Pergams, O.R.W.; Zaradic, P.A. Is love of nature in the US becoming love of electronic media? 16-year downtrend in national park visits explained by watching movies, playing video games, internet use, and oil prices. J. Environ. Manag. 2006, 80, 387-393. [CrossRef]

80. Ruiz Pulpón, Á.R.; Cañizares Ruiz, M.D.C. Potential of vineyard landscapes for sustainable tourism. Geoscience 2019,9 , 472. [CrossRef]

81. Santoro, A.; Venturi, M.; Agnoletti, M. Agricultural heritage systems and landscape perception among tourists. The case of Lamole, Chianti (Italy). Sustainability 2020, 12, 3509. [CrossRef]

82. Cortés, M.E.C. Sequía, degradación ambiental, trabajo y educación: Un breve comentario sobre la realidad actual de las comunidades agrícolas de la provincia del Limarí Chile. Idesia 2016, 34, 73-76. [CrossRef]

83. Ruíz Peyré, F. ¿Nacer en el campo-morir en la ciudad?: Exclusión y expulsión de los jóvenes de áreas rurales en América Latina. Rev. Electr. Teoría Educ. 2008, 9, 181-195. [CrossRef] 